\title{
Differential distribution and expression of leptin and the functional leptin receptor in major salivary glands of humans
}

\author{
J Bohlender ${ }^{1,2}, \mathbf{M ~ R a u h}^{3}$, J Zenk ${ }^{1}$ and $\mathbf{M ~ G r o ̈ s c h l ~}^{3}$ \\ ${ }^{1}$ Department of Otorhinolaryngology, University of Erlangen-Nürnberg, Germany \\ ${ }^{2}$ Department of Phoniatrics and Paediatric Audiology, Münster University Hospital, Münster, Germany \\ ${ }^{3}$ Department of Paediatrics, University of Erlangen-Nürnberg, Germany \\ (Requests for offprints should be addressed to M Gröschl, Klinik für Kinder und Jugendliche, Loschgestrasse 15, 91054 Erlangen, Germany; \\ Email: michael.groeschl@kinder.imed.uni-erlangen.de)
}

\begin{abstract}
Leptin plays a central role in the regulation of food intake and energy expenditure in rodents. However, it has become clear that this hormone has more than only a satiety-inducing function, and that there are other sources of leptin, such as the central nervous system, placenta and the gastrointestinal tract in addition to adipose tissue. Knowing about the important role of the salivary glands in food intake and digestion, it was the objective of the present study to investigate how leptin and its receptor are expressed and distributed in the major salivary glands of humans. We found leptin distributed throughout the major salivary glands with obvious intracellular concen-
\end{abstract}

trations in granula. In contrast, immunostaining for the leptin receptor was found exclusively in the membranes of the glandular cells. A high density of the leptin receptor was localised in the epithelia of the duct lumen. PCR analysis proved the autonomous expression of leptin by the salivary glands independently from adipocytes. Accordingly the long receptor isoform was expressed by any examined tissue. In the light of recent findings of leptin influencing the growth of rodent salivary glands, the presence and distribution of leptin and its receptor suggests an autocrine role of salivary leptin within the glands.

Journal of Endocrinology (2003) 178, 217-223

\section{Introduction}

Leptin is a mainly adipocyte-derived hormone which influences food intake and energy expenditure by interaction with receptors in the feeding centres of the hypothalamus (Hirschberg 1998). Especially for rodents (Air et al. 2002) and even birds (Lohmus et al. 2003) this influence of leptin on nutrition has been proved, whereas it remains still unclear whether this special role of the cytokine has similar importance for humans.

However, an increasing number of studies have shown that other tissues, such as the central nervous system (Morash et al. 1999), the placenta (Dötsch et al. 1999) and the gastrointestinal tract (Bado et al. 1998) are additional sources of leptin. Recently we demonstrated the expression of leptin by the human salivary glands (Gröschl et al. 2001). Other authors have shown a direct atrophic effect of leptin on the salivary glands of rats (Higa et al. 2002). This has led to the hypothesis that leptin released into saliva might have additional 'non-anorexic' effects in the upper gastrointestinal tract, as has been demonstrated in vivo for the stomach using recombinant leptin (Konturek et al. 1999a, 2001).

Certain effects appear obvious, since salivary leptin shows diverse physiological rhythmicities in humans, such as diurnal ones (Randeva et al. 2003) and a clear dependence on the phase of the menstrual cycle (Gröschl et al. 2002).

Leptin signalling occurs after binding to various receptor isoforms (ob- $\mathrm{R}_{\mathrm{a}}$ to ob- $\mathrm{R}_{\mathrm{e}}$ ) which are located ubiquitously (Halaas \& Friedman 1997, Löllmann et al. 1997, Bjorbaek et al. 1998) and introduce different modes of signal transduction (Sweeney 2002). It is not yet clear whether salivary leptin plays a role as a ligand of gastrointestinal receptors, localised in the mucosa of the stomach (Bado et al. 1998, Breidert et al. 1999) and in other parts of the gastrointestinal tract (Morton et al. 1998). However, infusion of recombinant adenovirus containing the cDNA for rodent leptin induced hyperleptinaemia in rats accompanied by atrophic changes of the salivary glands (Higa et al. 2002). These findings suggest that the proliferation of salivary gland cells was reduced by an nonanorexic effect of leptin. However, our own observations showed that leptin enhances the proliferation of human oral keratinocytes in vitro, as has been described for human and murine keratinocytes in cutaneous wound repair (Goren et al. 2003). This is underlined by various other studies indicating that leptin acts in a pro-proliferative way in many cell types (Tsuchiya et al. 1999, Wolf et al. 1999, Martin Romero et al. 2000, Park et al. 2001). 
Table 1 List of primers used for RT-PCR determination of human leptin, the long receptor isoform ob- $\mathrm{R}_{\mathrm{b}}$, and the adipocyte-specific protein apM-1

\begin{tabular}{|c|c|c|}
\hline & Direction & Sequence \\
\hline \multicolumn{3}{|l|}{ Gene product } \\
\hline \multirow[t]{2}{*}{ Leptin } & Sense & $5^{\prime}$ CCA TCC AAA AAG TCC AAG ATG ACA CCA AAA 3' \\
\hline & Antisense & 5' CCA TGC AAT GCT CTT CAA TCC TGG AGA TAC C 3' \\
\hline \multirow[t]{2}{*}{ Leptin nested } & Sense & 5' ACC CCA TCC TGA CCT TAT CCA AGA TGG ACC 3' \\
\hline & Antisense & 5' GCA AGT GGC AGC TCT TAG AGA AGG CCA GC 3' \\
\hline \multirow[t]{2}{*}{$o b-R_{b}$} & Sense & 5' CAA GGA CTT AAT TTT CAG AAG CCA ACG 3' \\
\hline & Antisense & 5' CCA TGA GCT ATT AGA GAA AGA ATC CTT CAA 3' \\
\hline \multirow[t]{2}{*}{ apM-1 } & Sense & 5' TाT GAA CCA AAG CTC AAA ACA ATC AAG ACC 3' \\
\hline & Antisense & 5' CAA TTG TAC TTC AAA GCA TCA CAG GAC C 3' \\
\hline \multirow[t]{2}{*}{ apM-1 nested } & Sense & 5' GAC ACT GTT ATC AGA AAT AGG AGA GTG G 3' \\
\hline & Antisense & 5' CAG GAC CAT TAA TCC TGA AAT CTT GAC C 3' \\
\hline
\end{tabular}

Therefore, with regard to a possible autocrine function of leptin in the glandular tissues and its role in the oral cavity, it was the objective of the present study to investigate the expression and distribution of leptin and its receptor in the major salivary glands in humans.

\section{Material and Methods}

\section{Sample material}

Submandibular, sublingual and parotid gland had been excised because of otorhinolaryngological disorders in the Department of Otorhinolaryngology of the University of Erlangen. The glandular tissues were not affected by the underlying disorders. Patients gave informed consent for the use of the tissue samples for research use. The specimens were stored at $-80{ }^{\circ} \mathrm{C}$ until use. Histological evaluation of the specimens was done on sections stained with haematoxylin-eosin.

\section{Immunohistochemistry}

Salivary glands were cut on a cryostat (Microm, Walldorf, Germany). Seven-micron thick frozen sections were fixed for $5 \mathrm{~min}$ in absolute alcohol, exposed to $10 \%$ normal bovine serum and incubated in a 1:100 dilution of antisera against recombinant human leptin (Gröschl et al. 2000) or human soluble leptin receptor (Lammert et al. 2001) for $45 \mathrm{~min}$ at room temperature. Negative controls were prepared by replacing the first antibody solution with PBS. The sections were then washed in PBS and exposed to a 1:100 dilution of the secondary rhodamine-tagged goat anti-rabbit antibody (Dianova, Hamburg, Germany) combined with a $4^{\prime}, 6$-diamidino-2-phenylindole (DAPI) 1:1000 solution, labelling for DNA.

The sections were examined under a Zeiss Axioplan fluorescence microscope. Photographs were taken under identical conditions with the same exposure times.

\section{$R N A$ extraction and reverse transcription}

Total RNA was extracted from the tissues using guanidine-thiocyanate acid phenol (TRIzol; WAK Chemie, Medical GmbH, Bad Homburg, Germany). Different from the manufacturer's protocol, we used $1 \mathrm{ml}$ TRIzol/100 mg glandular tissue and added $400 \mu \mathrm{CHCl}_{3}$. RNA concentration was determined spectrophotometrically. One microgram of RNA was reverse transcribed in a volume of $20 \mu \mathrm{l}$ at $39^{\circ} \mathrm{C}$ for $60 \mathrm{~min}$ (all chemicals were obtained from Boehringer, Mannheim, Germany).

Nested RT-PCR yielded a $158 \mathrm{bp}$ fragment of leptin cDNA. Following an initial denaturation at $94{ }^{\circ} \mathrm{C}(2 \mathrm{~min})$, samples were PCR amplified (25 cycles). Each cycle consisted of denaturation at $94{ }^{\circ} \mathrm{C}$, annealing at $67^{\circ} \mathrm{C}$ and extension at $72{ }^{\circ} \mathrm{C}$. To examine whether the leptinspecific signal was caused by contamination of the gland tissues with adipocytes, a nested RT-PCR for adipocytespecific apM-1 mRNA (Schaffler et al. 1998) was carried out. Nested RT-PCR yielded a $292 \mathrm{bp}$ fragment of apM-1 cDNA. In contrast to the amplification of leptin cDNA, the annealing temperature for apM-1 cDNA was $62{ }^{\circ} \mathrm{C}$. For the receptor no additional nested primers were used. The size of the fragment of ob- $\mathrm{R}_{\mathrm{b}}$ was $435 \mathrm{bp}$. The initial denaturation occurred at $94{ }^{\circ} \mathrm{C}$ for $2 \mathrm{~min}$. Each amplification cycle consisted of denaturation at $94^{\circ} \mathrm{C}$, annealing at $67{ }^{\circ} \mathrm{C}$ and extension at $72{ }^{\circ} \mathrm{C}$.

After PCR amplification, cDNA was analysed by electrophoresis on 1\% agarose in Tris-borate buffer and visualised by ethidium bromide staining. Human placenta and fat tissue served as positive controls, water as negative control. Primers for RT-PCR are listed in Table 1.

\section{Results}

Leptin was localised ubiquitously in the parotid, sublingual and submandibular glands. The leptin-specific rhodamine 

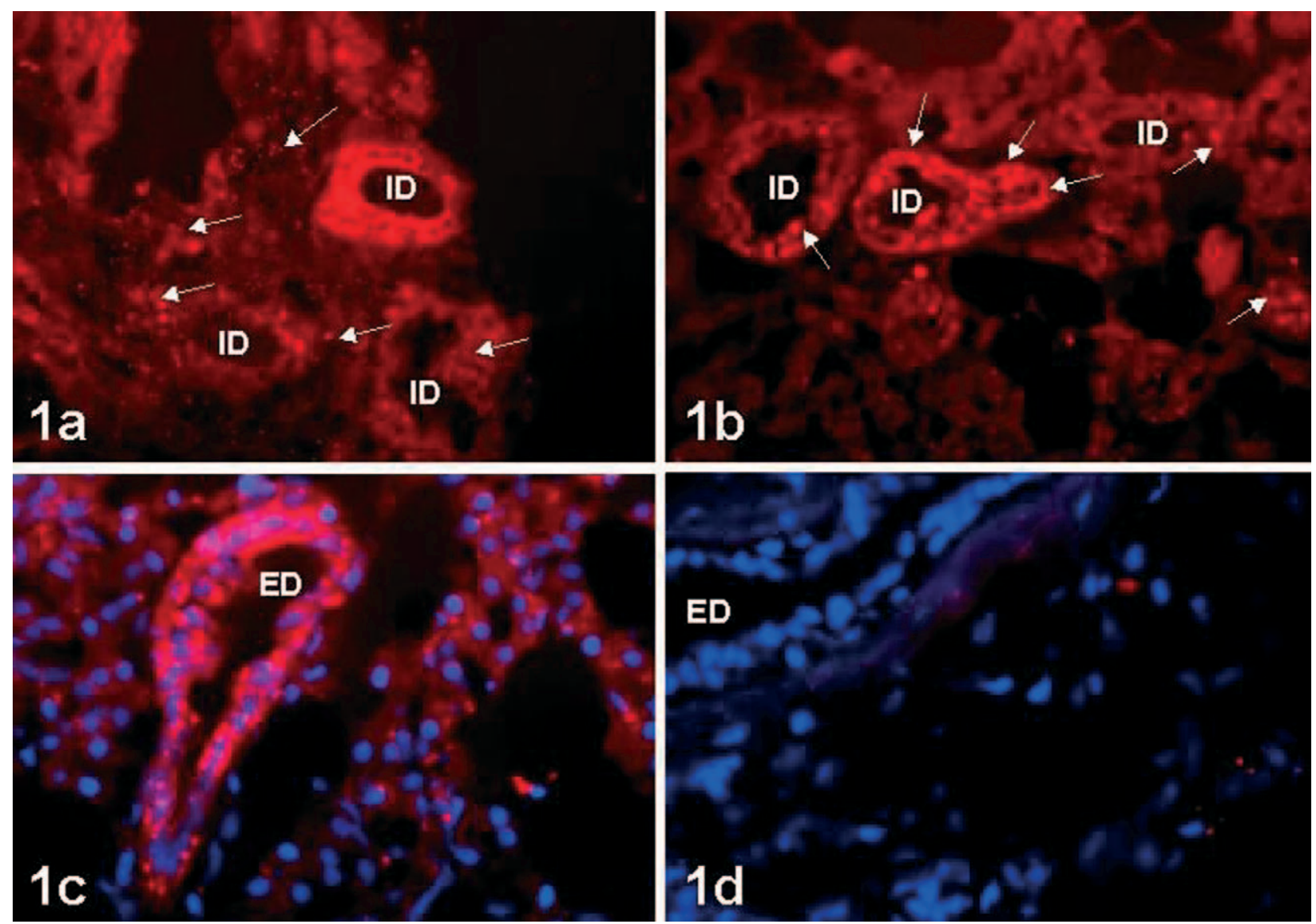

Figure 1 Rhodamine staining of leptin in $7 \mu \mathrm{m}$ sections of human salivary glands $(\times 200)$ with DAPI staining (c and d) of the DNA. (a) Submandibular gland: intercalated ducts (ID); (b) sublingual gland: intercalated ducts (ID); (c) sublingual gland: excretory duct (ED); (d) negative control: excretory duct. Granular staining for leptin was found all over the glandular tissues (arrows) with further concentration in the epithelia of the ducts. The cellular structure of the salivary ducts is clarified by the distribution of the DAPI staining in (c and d).

staining was found ubiquitously in acinar endpieces and the salivary ducts of the glands (Fig. 1). A distinct concentration occurred in granula, found in both acini and ducts (indicated by arrows in Fig. 1a and b). Further intense rhodamine staining was present in the epithelia of the salivary ducts (Fig. 1c). The blue DAPI staining localises the DNA, exemplified in Fig. 1c and d, to clarify the cellular structure. Immunoreactivity was absent in the buffer controls (Fig. 1d).

In contrast to the widespread granular distribution of leptin, rhodamine staining for ob-R was observed exclusively in the cell membranes. The staining was thereby more intense in those membranes directed towards the lumina of the salivary ducts and in those membranes which demarcate the acinar endpieces.

Parotid gland (Fig. 2a: acinar endpieces), submandibular gland (Fig. 2b: acini) and sublingual gland (Fig. 2c: excretory duct) presented similar staining for ob-R in the membranes surrounding the DAPI-stained nuclei. More- over, intense rhodamine staining was found in the membrane epithelia of the ducts, as demonstrated in Fig. 2c showing details of an excretory duct in the sublingual gland. A negative control (absence of specific antiserum) is shown in Fig. 2d.

Since PCR amplification for leptin using the outer primer set yielded bands in the parotid and the sublingual gland only, but not in the submandibular gland and the oral mucosa, a further amplification of this PCR product with a nested primer set was added. The nested RT-PCR then yielded the expected $158 \mathrm{bp}$ fragment of leptin cDNA in all large salivary glands as well as in oral mucosa (Fig. 3A).

Although the adipocyte-specific marker apM-1 was present in the parotid and sublingual glands, yielding a $292 \mathrm{bp}$ fragment, it was not detected in the submandibular gland and oral mucosa even after nested PCR (Fig. 3B).

Furthermore, expression of ob- $\mathrm{R}_{\mathrm{b}}$ mRNA was present in all examined tissues (Fig. $3 \mathrm{C}$ ). For the receptor no 

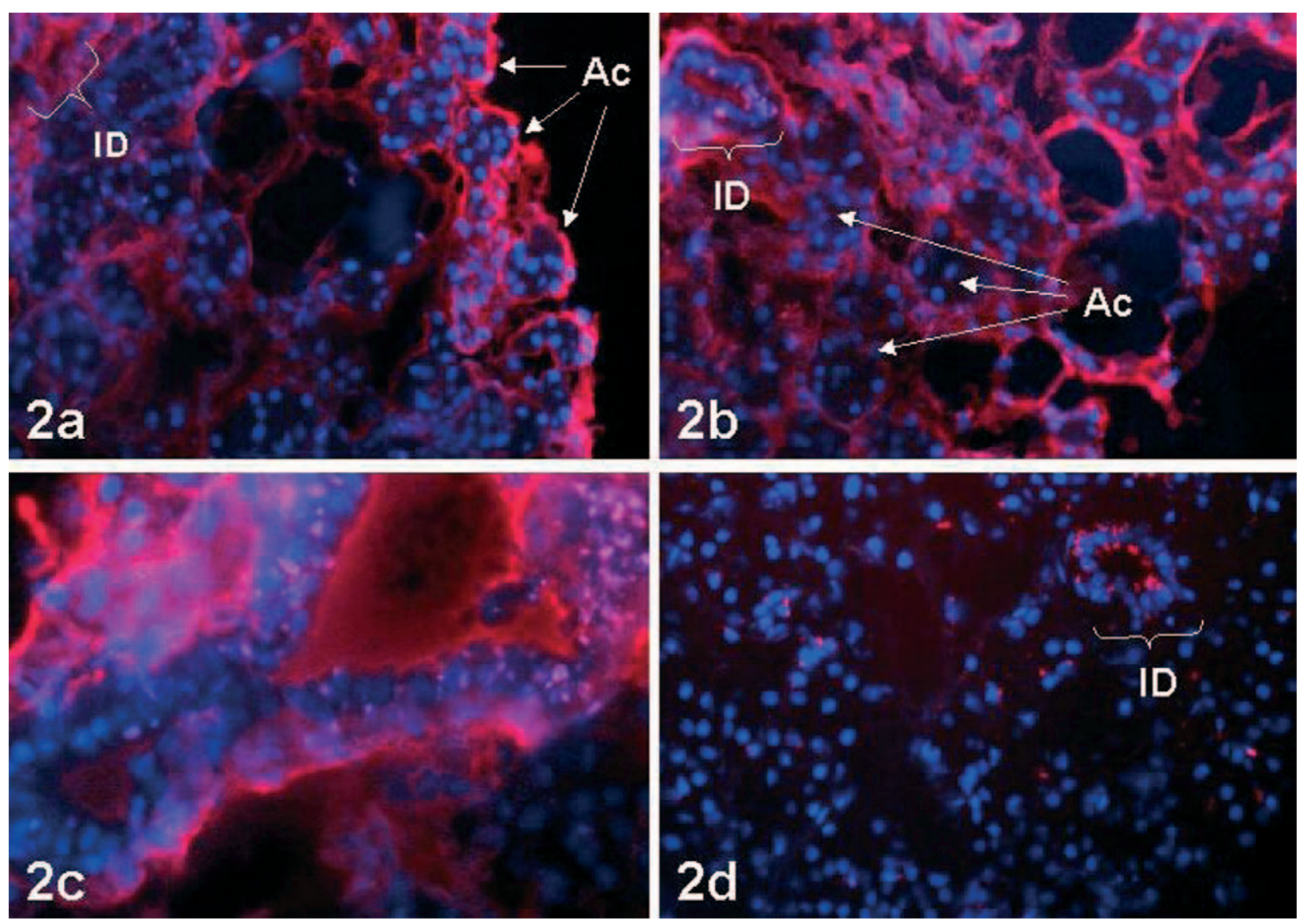

Figure 2 Rhodamine staining of ob-R in $7 \mu \mathrm{m}$ sections of human salivary glands $(\times 200)$ with DAPI staining of the cell nuclei. (a) Parotid gland: excretory duct (ED); (b) submandibular gland: acinar endpieces (Ac) and intercalated duct (ID); (c) sublingual gland: acinar endpieces (Ac) and intercalated duct (ID); (d) negative control. Rhodamine staining was localised exclusively in the membranes of the cells of both the acini and the salivary ducts. The cellular structure of the acinar endpieces and the salivary ducts is clarified by the distribution of the DAPI staining.

additional nested PCR was necessary. The size of the fragment of ob- $\mathrm{R}_{\mathrm{b}}$ was $435 \mathrm{bp}$.

\section{Discussion}

A proliferative effect of leptin has been described for various organs and tissues (Konturek et al. 1999a, Wolf et al. 1999, Frank et al. 2000). The recent discovery of both leptin and leptin receptors in the stomach (Bado et al. 1998, Cinti et al. 2000) and the presence of leptin in saliva (Gröschl et al. 2001) has led to further questions about peripheral leptin actions, which may influence food uptake, digestion or mucosal proliferation in a still unknown manner.

In the present study, we could show that leptin and its receptor ob-R have dissimilar distribution within the salivary glands. The concentration of the cytokine in distinct granula is in line with the immunohistochemical localisation of leptin in other tissues (Tsuruo et al. 1996, Cinti et al. 1997, Sobhani et al. 2000). This leads to our hypothesis that the peptide is stored within the glandular cells before its release into saliva. This might also explain why a nested PCR was necessary to detect leptin expression in any examined tissue. Our finding of leptin mRNA expression in the oral mucosa and the submandibular gland without parallel apM-1 mRNA expression underlines the idea of an adipocyteindependent leptin production by the salivary glands and the oral mucosa.

In contrast, ob- $\mathrm{R}$ was localised exclusively in the membranes of the glandular cells with further intense staining in the luminal epithelia of the salivary ducts. As in neuronal tissues (Funahashi et al. 2000, Iqbal et al. 2001), the presence of the receptor protein indicates that leptin derived from salivary glands acts directly via an autocrine 

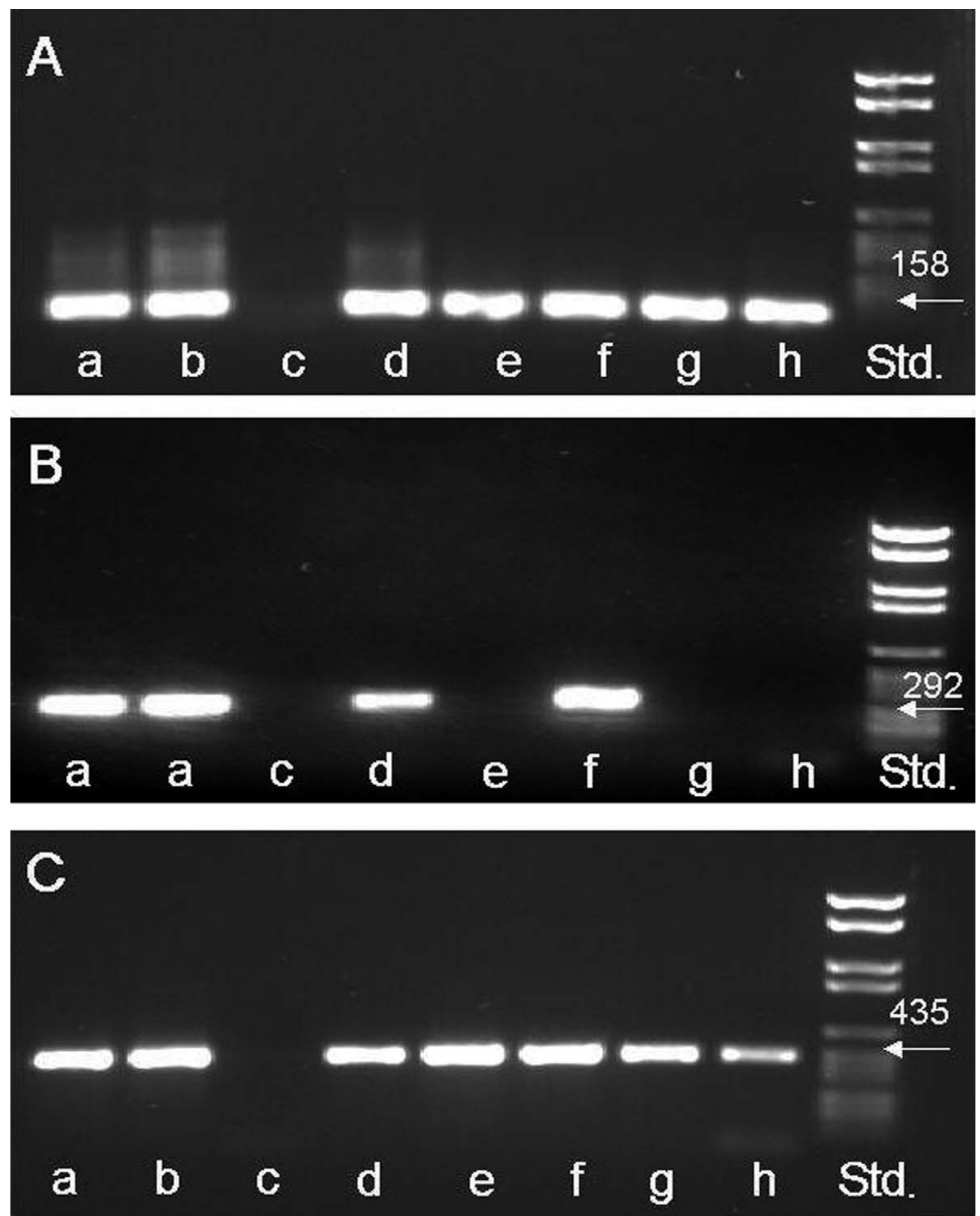

Figure 3 mRNA expression of leptin (A), the adipocyte-specific apM-1 (B), and the functional leptin receptor ob- $R_{b}(C)$, in human oral mucosa and salivary glands: a, adipose tissue (positive control); b, placenta (positive control); $c$, water (negative control); $d$, sublingual gland; e, submandibular gland; $f$, parotid gland; $g$ and $h$, oral mucosa; Std, DNA marker. For the determination of apM-1, adipose tissue was used twice as positive control (two ' $a$ ' lanes). Arrows indicate the expected size of the PCR products. 
activation. In addition to a postulated autocrine action of salivary leptin, which may be in the context of growth regulation of the glands (Higa et al. 2002), other gastrointestinal actions of this hormone appear possible. It has been shown by microelectrode recording that direct application of leptin into the stomach leads to neuronal activities in the brainstem of rodents (Yuan et al. 1999), possibly through vagal fibres projecting from the stomach to the caudal part of the brainstem. Furthermore, gastric application of leptin has been shown to reduce pepsin secretion and gastric acid production in rats (Brzozowski et al. 1999). However, interaction with gastric peptides as described for cholecystokinin and ghrelin seems not to be the only target of gastrointestinal leptin action. Moreover leptin seems to have a strong gastroprotective function (Brzozowski et al. 1999, Konturek et al. 1999a,b), either by inducing proliferation of the gastric mucosa itself or via up-regulation of further growth factors.

It must be mentioned that our protein analysis of the leptin receptor in glandular tissues is not able to differentiate between the long receptor isoform ob- $R_{b}$ and other truncated forms such as ob- $\mathrm{R}_{\mathrm{a}}$. We used an antibody raised against the soluble leptin receptor sob-R (Lammert et al. 2001), which is identical to the extracellular domain of the membrane-bound isoforms. Therefore we can state that there are extracellular binding sites for salivary leptin within the glands, located in the cell membranes with a clear concentration in membranes demarcating the acinar endpieces and salivary duct lumina. PCR analysis, however, proved the expression of the ob- $\mathrm{R}_{\mathrm{b}}$ isoform. This indicates that this so-called functional receptor isoform was responsible for the rhodamine staining.

A recently published work also focused on immunohistochemical determination of leptin and its receptor in submandibular and parotid gland (De-Matteis et al. 2002). Interestingly this study could determine immunoreactivity for leptin within salivary microglobules, whereas the seromucous material was negative. This finding underlines our hypothesis of an active release of the hormone into saliva.

In summary, this study suggests a functional role of salivary leptin in the salivary glands and the oral cavity. Certainly it remains to be investigated why hyperleptinaemia (in a transfection experiment) leads to weight loss of the salivary glands themselves (Higa et al. 2002), whereas salivary leptin increases proliferation of oral keratinocytes in vitro (Gröschl et al. 2003). Maybe negative feedback loops can explain the controversial action of leptin in the glands and the oral cavity.

\section{Acknowledgements}

We gratefully thank Dr Jürgen Kratzsch (ILM, University of Leipzig, Germany) for the supply of sob-R antiserum and Mrs Patricia Schmid for linguistic editing.

\section{References}

Air EL, Benoit SC, Clegg DJ, Seeley RJ \& Woods SC 2002 Insulin and leptin combine additively to reduce food intake and body weight in rats. Endocrinology 143 2449-2452.

Bado A, Levasseur S, Attoub S, Kermorgant S, Laigneau JP, Bortoluzzi MN, Moizo L, Lehy T, Guerre Millo M, Le-Marchand Brustel Y et al. 1998 The stomach is a source of leptin. Nature 394 790-793.

Bjorbaek C, Elmquist JK, Michl P, Ahima RS, van Bueren A, McCall AL \& Flier JS 1998 Expression of leptin receptor isoforms in rat brain microvessels. Endocrinology 139 3485-3491.

Breidert M, Miehlke S, Glasow A, Orban Z, Stolte M, Ehninger G, Bayerdorffer E, Nettesheim O, Halm U, Haidan A et al. 1999 Leptin and its receptor in normal human gastric mucosa and in Helicobacter pylori-associated gastritis. Scandinavian Journal of Gastroenterology 34 954-961.

Brzozowski T, Konturek PC, Konturek SJ, Pajdo R, Duda A, Pierzchalski P, Bielanski W \& Hahn EG 1999 Leptin in gastroprotection induced by cholecystokinin or by a meal. Role of vagal and sensory nerves and nitric oxide. European Journal of Pharmacology 374 263-276.

Cinti S, Frederich RC, Zingaretti MC, De-Matteis R, Flier JS \& Lowell BB 1997 Immunohistochemical localization of leptin and uncoupling protein in white and brown adipose tissue. Endocrinology $138797-804$.

Cinti S, Matteis R, Pico C, Ceresi E, Obrador A, Maffei C, Oliver J \& Pulou A 2000 Secretory granules of endocrine and chief cells of human stomach mucosa contain leptin. International Journal of Obesity 24 789-793.

De-Matteis R, Puxeddu R, Riva A \& Cinti S 2002 Intralobular ducts of human major salivary glands contain leptin and its receptor. Journal of Anatomy 201 363-370.

Dötsch J, Nusken KD, Knerr I, Kirschbaum M, Repp R \& Rascher W 1999 Leptin and neuropeptide Y gene expression in human placenta: ontogeny and evidence for similarities to hypothalamic regulation. Journal of Clinical Endocrinology and Metabolism $\mathbf{8 4}$ 2755-2758.

Frank S, Stallmeyer B, Kampfer H, Kolb N \& Pfeilschifter J 2000 Leptin enhances wound re-epithelialization and constitutes a direct function of leptin in skin repair. Journal of Clinical Investigation 106 501-509.

Funahashi H, Ryushi T, Mizushima H, Katoh S \& Shioda S 2000 Ultrastructural localization of the receptor for leptin in the rat hypothalamus. Hormones and Behaviour 37 327-334.

Goren I, Pfeilschifter J \& Frank S 2003 Determination of leptin signaling pathways in human and murine keratinocytes. Biochemical and Biophysical Research Communications 303 1080-1085.

Gröschl M, Wagner R, Dörr HG, Blum WF, Rascher W \& Dötsch J 2000 Variability of leptin values measured from different sample matrices. Hormone Research 54 26-31.

Gröschl M, Rauh M, Wagner R, Neuhuber W, Metzler M, Tamgüney G, Zenk J, Schoof E, Dörr HG, Blum WF et al. 2001 Identification of leptin in human saliva. Journal of Clinical Endocrinology and Metabolism 86 5234-5239.

Gröschl M, Rauh M, Dörr HG, Blum WF, Rascher W \& Dötsch J 2002 Salivary leptin during the menstrual cycle and its relation to progesterone. Fertility and Sterility 77 1306-1307.

Halaas JL \& Friedman JM 1997 Leptin and its receptor. Journal of Endocrinology 155 215-216.

Higa M, Shimabukuro M, Fukuchi M, Komiya I \& Takasu N 2002 Atrophic change of rat salivary gland during adenovirus-induced hyperleptinemia. Biochemical and Biophysical Research Communications $291675-679$.

Hirschberg AL 1998 Hormonal regulation of appetite and food intake. Annals of Medicine 30 7-20.

Iqbal J, Pompolo S, Murakami T, Grouzmann E, Sakurai T, Meister B \& Clarke IJ 2001 Immunohistochemical characterization of 
localization of long-form leptin receptor $\mathrm{OB}-\mathrm{Rb}$ in neurochemically defined cells in the ovine hypothalamus. Brain Research 920 55-64.

Konturek PC, Brzozowski T, Sulekova Z, Meixner H, Hahn EG \& Konturek SJ 1999a Enhanced expression of leptin following acute gastric injury in rat. Journal of Physiology and Pharmacology $\mathbf{5 0}$ 587-595.

Konturek PC, Konturek SJ, Brzozowski T \& Hahn EG 19996 Gastroprotection and control of food intake by leptin. Comparison with cholecystokinin and prostaglandins. Journal of Physiology and Pharmacology 50 39-48.

Konturek PC, Brzozowski T, Sulekova Z, Brzozowska I, Duda A, Meixner H, Hahn EG \& Konturek SJ 2001 Role of leptin in ulcer healing. European Journal of Pharmacology 414 87-97.

Lammert A, Kiess W, Bottner A, Glasow A \& Kratzsch J 2001 Soluble leptin receptor represents the main leptin binding activity in human blood. Biochemical and Biophysical Research Communications 283 982-988.

Lohmus M, Sundstrom LF, El Halawani M \& Silverin B 2003 Leptin depresses food intake in great tits Parus major. General and Comparative Endocrinology 131 57-61.

Löllmann B, Gruninger S, Stricker-Krongrad A \& Chiesi M 1997 Detection and quantification of the leptin receptor splice variants $\mathrm{Ob}-\mathrm{Ra}, \mathrm{b}$, and, e in different mouse tissues. Biochemical and Biophysical Research Communications 238 648-652.

Martin Romero C, Santos Alvarez J, Goberna R \& Sanchez Margalet V 2000 Human leptin enhances activation and proliferation of human circulating T lymphocytes. Cellular Immunology 199 15-24.

Morash B, Li A, Murphy PR, Wilkinson M \& Ur E 1999 Leptin gene expression in the brain and pituitary gland. Endocrinology 140 $5995-5998$.

Morton NM, Emilsson V, Liu YL \& Cawthorne MA 1998 Leptin action in intestinal cells. Journal of Biological Chemistry 273 26194-26201.

Park HY, Kwon HM, Lim HJ, Hong BK, Lee JY, Park BE, Jang Y, Cho SY \& Kim HS 2001 Potential role of leptin in angiogenesis: leptin induces endothelial cell proliferation and expression of matrix metalloproteinases in vivo and in vitro. Experimental and Molecular Medicine 33 95-102.

Randeva H, Karteris E, Sailesh S, O'Hare P \& Hillhouse EW 2003 Circadian rhythmicity of salivary leptin in healthy subjects. Molecular Genetics and Metabolism 78 229-235.

Schaffler A, Langmann T, Palitzsch KD, Scholmerich J \& Schmitz G 1998 Identification and characterization of the human adipocyte apM-1 promoter. Biochimica et Biophysica Acta 1399 187-197.

Sobhani I, Bado A, Vissuzaine C, Buyse M, Kermorgant S, Laigneau JP, Attoub S, Lehy T, Henin D, Mignon M \& Lewin MJ 2000 Leptin secretion and leptin receptor in the human stomach. Gut $\mathbf{4 7}$ 178-183.

Sweeney G 2002 Leptin signalling. Cellular Signalling 14 655-663.

Tsuchiya T, Shimizu H, Horie T \& Mori M 1999 Expression of leptin receptor in lung: leptin as a growth factor. European Journal of Pharmacology 365 273-279.

Tsuruo Y, Sato I, Iida M, Murakami T, Ishimura K \& Shima K 1996 Immunohistochemical detection of the ob gene product leptin in rat white and brown adipocytes. Hormone and Metabolic Research 28 753-755.

Wolf G, Hamann A, Han DC, Helmchen U, Thaiss F, Ziyadeh FN \& Stahl RA 1999 Leptin stimulates proliferation and TGF-beta expression in renal glomerular endothelial cells: potential role in glomerulosclerosis. Kidney International 56 860-872.

Yuan CS, Attele AS, Wu JA, Zhang L \& Shi ZQ 1999 Peripheral gastric leptin modulates brain stem neuronal activity in neonates. American Journal of Physiology 277 G626-G630.

Received 30 March 2003

Accepted 23 May 2003

Made available online as an

Accepted Preprint 2 June 2003 